\title{
Social and Psychological Features of Hardiness in Personality of Students of Higher Education Institutions
}

\author{
Características sociales y psicológicas de la resistencia en la \\ personalidad de los estudiantes de instituciones de educación \\ superior \\ Zara A-M. Albakova" \\ Ingush State University, Magas, Russia \\ ORCID: http://orcid.org/0000-0002-2283-2030
}

Kirill S. Ezhov

Ural State University of Economics, Yekaterinburg, Russia

ORCID: http://orcid.org/0000-0002-7694-0387

Sofiya Sh. Umerkaeva

Moscow City University, Moscow, Russia ORCID: http://orcid.org/0000-0002-6057-2364

Marina A. Antonova

Moscow City University, Moscow, Russia

ORCID: http://orcid.org/0000-0001-7864-420X

Alexey V. Kidinov

Russian State Social University, Moscow, Russia

ORCID: http://orcid.org/0000-0002-1826-208X

\section{Zakhrat I. Aigumova}

Moscow State Pedagogical University, Moscow, Russia

ORCID: http://orcid.org/0000-0002-4289-719X

\section{Yuliya V. Klepach}

Voronezh State Pedagogical University, Voronezh, Russia

ORCID: http://orcid.org/0000-0002-3315-3375

*Correspondence

Email: zara.albakova@yandex.ru
Cite as: 


\section{Summary}

The topicality and significance of the study is determined by the fact that life and activity of a person in contemporary socio-economic conditions are inextricably connected with the constant impact of adverse social, political, economic and other factors on him. These factors are accompanied by the emergence of various kinds of difficult life situations, as a result of which stress develops in a person. In the student milieu, stress arises under the influence of difficulties associated with both the learning process and life circumstances. The paper presents the results of an empirical study of socio-psychological features of hardiness in students of higher educational institutions. The methods of research comprised: theoretical analysis, empirical research (testing), qualitative analysis of the obtained data, mathematical and statistical data processing (SPSS Statistics, Excel). Testing included the following psycho-diagnostic tools: the author's questionnaire for assessing stressful situations; McCrae-Costa Five-Factor Personality Questionnaire (The Big Five dimensions); "Hardiness test"; Self-attitude technique. The validity and reliability of the study results was ensured by the initial methodological positions, the use of proven tools, sample representativeness of the research, as well as mathematical processing of data with the use of a software package for statistical analysis. As a result of the study, it was proved that emotion-focused ways of overcoming stress associated with a decrease in tension and a change in attitude to emerging difficulties prevail among the students of both the experimental and control groups. A high level of stress was found in the majority of subjects. In order to reduce this stress, it is necessary for students to form special skills to overcome it. In addition, an analysis of the psychological factors of students' hardiness made it possible to determine the main areas of their psychological support in overcoming difficult life situations (development of qualities that form the core of students' personal adaptive potential, the formation of their social competency, enrichment of social networks, as well as learning ways to find and accept social support).

Keywords: Hardiness; Higher Professional Education; Stress; Coping Behavior; Coping Strategies; Personal Resource.

\section{Resumen}

La actualidad y la importancia del estudio están determinadas por el hecho de que la vida y la actividad de una persona en condiciones socioeconómicas contemporáneas están inextricablemente conectadas con el impacto constante de factores sociales, políticos, económicos y otros adversos en él. Estos factores están acompañados por la aparición de varios tipos de situaciones difíciles de la vida, como resultado de lo cual el estrés se desarrolla en una persona. En el entorno estudiantil, el estrés surge bajo la influencia de dificultades asociadas tanto con el proceso de aprendizaje como con las circunstancias de la vida. El artículo presenta los resultados de un estudio empírico de las características sociopsicológicas de la resistencia en estudiantes de instituciones de educación superior. Los métodos de investigación comprendieron: análisis teórico, investigación empírica (pruebas), análisis cualitativo de los datos obtenidos, procesamiento de datos matemáticos y estadísticos (SPSS Statistics, Excel). Las pruebas incluyeron las siguientes herramientas de psico-diagnóstico: el cuestionario del autor para evaluar situaciones estresantes; Cuestionario de personalidad de cinco factores McCrae-Costa (Las cinco grandes dimensiones); "Prueba de resistencia"; Técnica de actitud propia. La validez y la fiabilidad de los resultados del estudio se garantizaron mediante las posiciones metodológicas iniciales, el uso de herramientas comprobadas, la representatividad de la muestra de la investigación, así como el procesamiento matemático de los datos con el uso de un paquete de software para el análisis estadístico. Como resultado del estudio, se demostró que las formas centradas en la emoción de superar el estrés asociado con una disminución de la tensión y un cambio de actitud ante las dificultades emergentes prevalecen entre los estudiantes de los grupos experimentales y de control. Se encontró un alto nivel de estrés en la mayoría de los sujetos. Para 
reducir este estrés, es necesario que los estudiantes formen habilidades especiales para superarlo. Además, un análisis de los factores psicológicos de la resistencia de los estudiantes permitió determinar las áreas principales de su apoyo psicológico para superar situaciones difíciles de la vida (desarrollo de cualidades que forman el núcleo del potencial de adaptación personal de los estudiantes, la formación de su sociedad). competencia, enriquecimiento de las redes sociales, así como aprender formas de encontrar y aceptar apoyo social).

Palabras clave: Resistencia; Educación profesional superior; Estrés; Comportamiento de Afrontamiento; Estrategias de Afrontamiento; Recursos Personales.

\section{Introduction}

Today, the problem of human behavior in difficult life situations is gaining topicality. The living conditions of a person in contemporary society can be called extreme, which is associated with many factors. A serious terrorist threat; environmental disasters; economic and political instability belong to such factors. Therefore, today the question of how to survive in difficult life situations and how to increase one's hardiness is very important.

A person's life and activity in contemporary socio-economic conditions is inextricably connected with the constant impact of unfavorable social, professional and other factors on him, accompanied by the emergence of various kinds of difficult life situations, as a result of which a person develops stress.

In the student milieu, stress arises under the influence of difficulties associated with both the learning process and life circumstances. In recent years, convincing evidence has been obtained that difficult life situations have a negative impact on the physical and mental state of students, being one of the major traumatic factors. In this regard, there is a need to form skills among students to overcome difficulties (Mitin et al., 2018; Goloshumova et al., 2019b; Miloradova \& Ishkov, 2019b; Salakhova et.al., 2019).

The essence of the "struggle" with difficult life situations, the "counteraction" to them is included both in prevention and in control of stress development (Bonkalo, Erofeeva \& Gorokhova, 2008).

The concept "overcoming" comprises various forms of human activity. It also embraces all types of interaction between the subject and objectives of an external or internal nature, problems that must be solved, avoided, brought under control, mitigated, etc.

S.K. Nartova-Bochaver (1997) points out that this concept began to be used not only in relation to extreme conditions, but also to describe the behavior of people in difficult life situations, under the chronic influence of destructive factors and everyday negative and joyful events. The ideographic study of personality in connection with the problem of psychological overcoming of life difficulties is actively carried out by L.I. Antsyferova (1994). As many authors note, the set of life situations and the repertoire of ways to resolve them change significantly throughout the course of a person's life, therefore the arsenal of individual strategies, their variations are quite diverse, and the interactions between the subject and situations are multivariate (Bodrov, 2006).

The variety of ways to overcome difficult life situations is determined by specific features of interaction between the subject and a stressful situation, not only due to the objective complexity, danger, harmfulness of a particular experienced situation, but also due to its subjective significance. Individual features of perception and assessment of a specific difficult situation are reflected in the search for ways to overcome it, which are reduced to solving a real 
problem or its emotional experience, correcting low self-esteem or regulating relationships with people. In this regard, two strategies of psychological overcoming proposed by R. Lazarus (1970) should be pointed out that are aimed at solving a problem (problem-oriented overcoming) or changing one's own attitude towards the situation (personality-based or emotion-focused coping) (Salakhova et al., 2018b; Mitin et al., 2017; Eniashina et al., 2018; Klimova et al., 2018; Kuprene \& Laptev, 2016).

\section{Literature Review}

First of all, we consider the very concept of "hardiness". D.A. Leontiev (2003) gives the following definition: "a measure of a person's ability to withstand a stressful situation, while maintaining internal balance and not reducing the success of activities" (Aleksandrova, 2004). In the work by N.V. Kalinina one can also find such a definition of this concept: "as a certain set of personal properties and behavioral reactions that allow one to constructively solve a difficult life situation" (Kalinina et al., 2018; Mitina et al., 2017).

The problem of hardiness is actively studied in foreign psychology. From the point of view of S. Maddi and D.M. Khoshaba (1994), the concept of "hardiness", or persistence, is used in the context of coping with stress, it reflects psychological viability and enhanced effectiveness of a person, and also is an indicator of a person's mental health. The personal quality of hardiness (resilience) emphasizes the attitudes that motivate a person to transform difficult life situations. Indicators of the ability to cope with life's challenges of a person is the ability to effectively manage one's internal resources. So, S. Maddi et al. (2002) identifies three characteristics of attitudes:

1) Commitment is defined as "the belief that involvement in what is happening gives the maximum chance to find something worthwhile and interesting to a person". If a person has developed a component of commitment, then he enjoys his own activities. A person with an undeveloped component of commitment experiences a feeling of rejection. "If you feel confident in yourself and that the world is generous, commitment is inherent in you".

2) Control is the belief that the struggle makes it possible to influence the outcome of what is happening, even if this influence is not absolute and success is not guaranteed. Such a person is confident in his abilities and will be able to transform a difficult situation in order to benefit from this situation.

3) Challenge is a person's persuasion that everything what happens to him contributes to his development through knowledge gained from experience - no matter whether it is positive or negative. A person who considers life as a way to gain experience perceives life difficulties as an opportunity for further development (Leontiev \& Rasskazova, 2006).

In modern Russian psychology, attempts are made to comprehend the personal features conducive to coping with life difficulties, the development of which will be the most important factor in overcoming difficulties (Agadzhanova, 2019; Efimova et al., 2018; Ishkov, 2014).

A.G. Maklakov (2001) asserts that a person's ability to adapt in a difficult situation depends on the psychological features of a person. These psychological characteristics of a person make up his personal adaptive potential, which includes the following specific features: neuropsychic stability, the level of development of which provides tolerance to stress; self-esteem of a person, which is the core of self-regulation and determines the degree of adequacy to perceive the conditions of activity and one's own capabilities; a sense of social support, leading to a sense of self-worth for others; a level of conflictedness in a person; experience of social communication. The author considers all these listed characteristics significant in assessing and predicting the success of adaptation to difficult and extreme situations, as well as in assessing the restoration rate of psychic balance. 
D.A. Leontiev (2003), in his turn, expands the concept of personality potential as a basic individual characteristic, the core of personality. Personal potential, according to A.N. Leontiev (1975), is an integral characteristic of the level of maturity of personality, and the main phenomenon of personality maturity and the form of manifestation of personality potential is precisely the phenomenon of self-determination of personality. Personal potential reflects the extent to which a person overcomes the given circumstances, ultimately the person overcomes himself, as well as the measure of the efforts he makes when working on herself and on the circumstances of her life.

From our positions, the manifestation of a person's hardiness is determined by the formation of his social competency as a special component of personal potential, which allows him to actively and constructively behave in a specific social situation, perceived by the person as difficult, to use external and internal resources to overcome difficulties (Erofeeva et al., 2019; Goloshumova et al., 2019a; Miloradova \& Ishkov, 2019a; Salakhova et al., 2018a).

By hardiness of a person we mean an integrative personal construct representing a system of knowledge about society, behavioral skills accepted in society, as well as a system of relationships manifested through a person's personal qualities, motivation, value orientations that make it possible to integrate external and internal resources to achieve socially significant goals and solve life problems in a constructive way of behavior (Safronova, 2019).

In the structure of hardiness, we identify two components: cognitive-behavioral, which includes the knowledge of a person about society and himself in society, social skills that ensure success in socially significant activities and interaction; motivational-personal component, including the motivation for self-realization and personal qualities that contribute to selfrealization in society.

In resolving life difficulties, we give the leading place to the motivational-personal component, since it is it that allows a person to withstand difficulties and forms the basis for mastering constructive ways of behavior in difficult life situations.

The identification of the components of the motivational-personal constituent is based on the concepts of the hardy personality proposed by S. Maddi et al. (2002), of experience proposed by F.E. Vasilyuk (1984), coping strategies and strategies of constructive behavior in difficult life situations proposed by L.F. Burlachuk and E.Yu. Korzhova (1998), E.Yu. Korzhova (2002) cointelligence by A.V. Libina (2008) and psychological overcoming by R.Kh. Shakurov (2003).

Manifestations of the person's hardiness in a difficult life situation are thought of as a dynamic process of achieving the optimal, in terms of personality development, correlation of its needs and behavior in a social context. We consider the mechanism of overcoming emotional and motivational barriers as the main mechanism of constructive behavior in a difficult situation. It is assumed that an emotional and cognitive assessment of one's own abilities to overcome problems, reflecting the motivational structure and strength of the person's "I", will allow one to determine the trends of positive, or, conversely, negative self-movement of a person. Overcoming difficulties is a dynamic process of transforming a situation owing to a change of its components: behavior or a personal attitude. That is, this is a process that leads to certain personality changes due to the mobilization of one's own resources (Kalinina, 2012).

In our opinion, it is the development of this ability that constitutes the main personal factor of hardiness.

In addition to the personality factors of students' hardiness, it seems important to us to highlight social factors, in particular social support. Social support is one of the most important milieu resources of overcoming in the form of information that brings the subject to an idea that 
he is loved, appreciated, taken care of, that he is a member of the social environment and has mutual obligations with it. The studies have shown that people who got different types of support from the family, friends, people who are significant to them, have better health, and can withstand everyday life difficulties and diseases more easily. Social support, mitigating the effect of stressors on the organism, has an effect on the preservation of health and well-being of the individual, facilitates adaptation and promotes the development of a person.

Social support is one of the most powerful social coping resources and is understood as guidance, feedback, and real resources that enable individuals to emotionally and instrumentally cope with stressful changes in life, as a reflection of a person's relationship with people from the immediate social environment who can feel empathy with him, can and want to help in the solution to existing problems. It mitigates the effects of stress in difficult situations and can be seen as interpersonal interactions in which one person experiences distress and another tries to provide support (Solovieva, 2016).

The immediate environment of a person, that is his family, is of primary importance in supporting him in a difficult life situation. In the contemporary world, it is the family that is considered as the "rear", as the source of the resource when a person encounters difficulty in life. The importance of the resource to overcome difficulties inherent in the immediate environment is manifested in such an integrated construct as satisfaction with family (kinship) relations. Satisfaction with relationships with close people allows a person to be confident that they feel empathy with him, can and want to help in solving problems and overcoming a difficult life situation. We believe that for students, it is family relations that make up the leading social and personal resource for overcoming difficulties in life.

\section{Materials and Methods}

Three hundred respondents participated in our study of the socio-psychological features of students' hardiness including 300 students from Ingush State University, Ural State University of Economics, Moscow City University, Russian State Social University, Moscow State Pedagogical University and Voronezh State Pedagogical University, and 300 students from the Moscow University of the Ministry of Internal Affairs of Russia Named After V.Y. Kikot. The age of the subjects ranged from 18 to 22 .

To study the social factors of hardiness, we divided the subjects into 2 groups: the experimental (students of the Moscow University of the Ministry of Internal Affairs of Russia Named After V.Y. Kikot) and control one (students of Ingush State University, Ural State University of Economics, Moscow City University, Russian State Social University, Moscow State Pedagogical University and Voronezh State Pedagogical University).

The following research methods were used: theoretical analysis, empirical research (testing), qualitative analysis of the obtained data, mathematical and statistical data processing (SPSS Statistics, Excel).

Testing included the following psycho-diagnostic tools: the author's questionnaire for identifying stressful situations; McCrae-Costa Five-Factor Personality Questionnaire (The Big Five) (Khromov, 2000); "Hardiness test" by D.A. Leontiev and E.I. Rasskazova (2006); a selfattitude technique by V.V. Stolin and S.R. Pantileev (Glukhanyuk, 2000).

The validity and reliability of the research results was ensured by the initial methodological positions, the use of proven tools, representativeness of the study sample, as well as mathematical processing of data with the use of a software package for statistical analysis.

\section{Results and Discussion}


To study the stresses that students face in difficult situations and the coping strategies they use, we conducted an experimental study with a common sample of respondents: 4th and 5th year students from all universities.

The experimental study consisted of the following stages:

1) At the first stage, difficult life situations were identified which were most common among students. For this purpose, the subjects were asked to describe the most typical situations in which they experience stress and evaluate the level of stress on a scale from 0 to 10 points.

Based on the answers received, the following difficult situations were identified: most often students (55\% of the subjects) experience stress associated with educational and professional activities. $15 \%$ of respondents experience stress associated with communication difficulties; $10 \%$ have stresses caused by special, unusual conditions. In $8 \%$ of the subjects, stress is associated with domestic problems, in $6 \%$ - with problems in the family and with a poor state of health - $4 \%$. In $2 \%$ - stress associated with material problems.

2) At the second stage, we determined the level of stress in students for which the subjects were offered the test "Susceptibility to stress". The results showed that $5 \%$ of the subjects have no signs of stress, $25 \%$ of the subjects have mild stress, $15 \%$ of the subjects have moderate stress, which is within the acceptable level of psychic stress.

It is significant that $45 \%$ of the subjects had stresses above the average level, and $10 \%$ of the subjects had high levels of stress, which had a significant impact on health and required measures to eradicate the causes and form coping skills.

3) To study the stress management strategies used by students, at the third stage of the study, the subjects were asked to answer the question: "What do you do to overcome stress in difficult situations?"

All the proposed methods of overcoming we divided into 2 groups:

1) Problem-oriented methods of overcoming, in which efforts are directed at solving the difficulties encountered.

The following methods were identified: in situations related to the learning process, $20 \%$ of the subjects noted that they are better prepared for classes. $2 \%$ - looking for a way out of this situation, engaged in something new.

In stressful situations caused by difficulties in communication, $4 \%$ of the respondents said that they persuade someone, $3 \%$ - smooth out the conflict.

2) Emotion-focused ways of overcoming associated with a change in their own attitudes towards the situation or in various ways to reduce tension.

Among the methods used to relieve tension, the subjects identified the following: $20 \%$ of respondents use self-hypnosis, $25 \%$ - calm themselves, $5 \%$ - relax, sleep, $4 \%$ take an active rest (walk, travel), listen to soothing music, show appropriate emotions (laughter, crying), communicate with other people, change the attitude to the problem.

One can see from the obtained results that emotion-focused ways of overcoming stress associated with a reduction in tension and a change in attitude to emerged difficulties prevail among the subjects. 
Due to the fact that majority of the subjects showed a high level of stress, it is necessary for students to develop special skills to overcome it. For this purpose, one can use various types of emotional-volitional training. One of the main tasks of such a training is the development of skills to recognize and classify difficult situations in terms of their controllability.

In controlled situations, it is necessary to form skills to use problem-overcoming strategies aimed at solving emerging problems. To this end, it is possible to develop the skills of analysis and resolution of emerging problem situations, training in time management, social skills, and self-confidence.

In situations with uncontrolled conditions, the main attention should be directed towards the development of emotion-focused coping strategies which include techniques that mitigate the negative effects of stress. These include methods of distracting or deliberately shifting attention to other activities in order to weaken the action of stress factors, changing thoughts and beliefs, as well as various relaxation techniques.

In the framework of the further study, we determined the level of students' hardiness. According to the results of the hardiness test, we can conclude that the average level of hardiness in students of both groups is very high. The hardiness index in the experimental group is (90) which is only 2 points lower than the index in the control group (92), with the norm being 80.72).

Further, to determine the psychological features of hardy personality, we used the Big Five technique. It describes five main paired factors, which in turn include five primary factors. The indicators for five factors were as follows: all respondents with a high level of hardiness have a high level in the factors of "attachment", "self-control". But the results obtained in the factor "expressiveness-practicality" were ambiguous: some of the subjects gave a high score in "expressiveness", and some in "practicality". This may indicate that hardiness does not depend on these personality indicators, and, in particular, on "curiosity", "inquisitiveness", "artistry", "sensitivity" and "plasticity". In addition, the analysis showed that an emotionally unstable person with a high level of anxiety can be hardy too.

Also, people with a high level of hardiness are characterized by an extraverted orientation of the psyche, as shown by the values of the C. Spearman rank correlation method ( $\mathrm{rs}=0.65$ with rscr $=0.35, \mathrm{p} \leq 0.01$ ), they are sociable, active, often take risks, they know how to develop empathy, they are able to cooperate, conscientiously and responsibly fulfill instructions. In addition, a person with a high level of hardiness will have a high level of self-acceptance ( $\mathrm{rs}=0.7$ at $\mathrm{rscr}=0.35, \mathrm{p} \leq 0.01$ ), such a person is in harmony with himself, he accepts his "I" completely, but he may suppose that others may not always have a positive attitude to him.

Thus, we could not find the significant influence of the social factor which is a certain difficult situation (in our study, these are the training features: a daily regimen, a constant stay in an educational institution, intergroup dynamics, etc.) on hardiness of an individual, but we were able to identify some tendency towards lower values of hardiness among students in the experimental group.

This means that the probability of high values of hardiness among students studying at civil universities is somewhat higher. Features such as expressiveness and practicality do not affect the level of hardiness. That is, such a person can equally trust in feelings and intuition and look for rational explanations and practical benefits in everything. Also, in the course our study, we found that if a person has a high level of hardiness, this does not mean that such a person will not experience a sense of anxiety. Hardy people can be disturbed by feelings about the future too; they do not always succeed in controlling their feelings and strong impulses completely.

\section{Conclusion}


The results obtained in the study indicate that emotion-focused ways to overcome stress associated with a decrease in tension and a change in attitude towards difficulties prevail in the students of both the experimental and control groups. The majority of the subjects showed a high level of stress. To overcome it, students need to form special skills. To solve this problem, various types of emotional-volitional training can be used. One of the main objectives of such training is the development of skills to recognize and classify difficult situations in terms of their controllability. In controlled situations, it is necessary to shape up skills to use strategies aimed at overcoming problems that arise. To this end, it is possible to develop the skills of analysis and resolution of emerging problem situations, training in time management, social skills, and selfconfidence. In situations with uncontrolled conditions, the main attention should be paid to the development of emotion-focused coping strategies, which include techniques that mitigate the negative effects of stress. These include methods of distracting or deliberately shifting attention to other activities in order to weaken the action of stress factors, changing thoughts and beliefs, as well as various relaxation techniques.

In addition, the results of the study demonstrated that all students with a high level of hardiness have a high level in the factors of "attachment" and "self-control". The results in the factor "expressiveness-practicality" were ambiguous: one part of the subjects had a high score in the indicator "expressiveness", the other part in "practicality". The data obtained indicate that hardiness does not depend on these personality indicators, and, in particular, on "curiosity", "inquisitiveness", "artistry", "sensitivity" and "plasticity".

In addition, the analysis showed that an emotionally unstable person with a high level of anxiety can also be hardy.

\section{Recommendations}

The analysis of psychological factors of students' hardiness allows us to determine the main areas of their psychological support in overcoming difficult life situations. The point is about the possibilities of developing the qualities that form the core of the students' personal adaptive potential, forming their social competency, enriching social networks, as well as learning how to find and accept social support.

\section{References}

Agadzhanova, E.R. (2019). Deviant behavior of teenagers: reasons, forms, prevention. Simbirsk Scientific Journal Vestnik, 4(38), 7-11.

Aleksandrova, L.A. (2004). To the concept of resilience. Siberian psychology today: a collection of scientific papers. M.M. Gorbatova, A.V. Sery, M.S. Yanitsky (Eds.). Kemerovo: Kuzbasvuzizdat, pp. 147-154.

Antsyferova, L.I. (1994). Personality in difficult living conditions: rethinking, transformation of situations and psychological defense. Psychological Journal, 15(1), 3-19.

Bodrov, V.A. (2006). Psychological stress: development and overcoming. Moscow: PER SE.

Bonkalo, T.I., Erofeeva, M.A. \& Gorokhova, I.V. (2008). The main categories and concepts of special pedagogy and psychology. Kolomna: KSPI.

Burlachuk, L.F. \& Korzhova, E.Yu. (1998). Psychology of life situations. Moscow: Russian Pedagogical Agency.

Efimova, O.I., Salakhova, V.B., Oshchepkov, A.A., Khudyakova, T.L. \& Deberdeeva, N.A. (2018). Antisuicidal Potential of the Person: Theory and Empirics Research. Modern Journal of Language Teaching Methods, 8(5), 510-517. 
Eniashina, N.G., Ovsyanik, O.A., Khammatova, R.S., Azyrkina, E.I., Vasyakin, B.S. \& Belogrud, I.N. (2018). Formation of the educational system of the Russian federation: gender differences. Modern Journal of Language Teaching Methods, 8(5), 501-509.

Erofeeva, M.A., Ulyanova, I.V., Plakhotnikova, I.V., Kurilyuk, Y.E., Egorov, V.A. \& Kochetkov, I.G. (2019). Reforming and developing socialization of children with limited abilities (mild intellectual disability). Electronic Journal of General Medicine, 16(2), em112.

Glukhanyuk, N.S. (2000). Workshop on psychodiagnostics. Moscow: Publishing house of the Moscow Psychological and Social Institute.

Goloshumova, G.S., Ershova, O.V., Salakhova, V.B., Kidinov, A.V., Nalichaeva, S.A. \& Yanysheva, V.A. (2019a). Information and educational environment of higher school as a factor of the formation of coping strategies in the structure of students' personality (ecological and psychological aspect). EurAsian Journal of BioSciences, 13(2), 18671874.

Goloshumova, G.S., Gribkova, O.V., Kidinov, A.V., Tkhugo, M.M., Chernova, O.E., Telysheva, N.N. \& Agadzhanova, E.R. (2019b). Specific features of life orientations among students and their interrelation with professional formation. Revista Praxis Educacional, 15(34), 673-682.

Ishkov, A.D. (2014). The features of self-organization of adults studying at technical university. Procedia - Social and Behavioral Sciences, 142, 54-58.

Kalinina, N.V. (2012). The strategy of behavior of marriage partners with varying degrees of satisfaction with the marriage in difficult life situations. Modern problems of science and education, 2. URL: https://www.science-education.ru/en/article/view?id=5760

Kalinina, N.V., Zaretskiy, V.V., Salakhova, V.B., Artamonova, E.G., Efimova, O.I. \& Lekareva, E.E. (2018). Psychological and pedagogical resources of security provision and prevention of internet risks and life threats among children and teenagers in the educational environment. Modern Journal of Language Teaching Methods, 8(8), 118129.

Khromov, A.B. (2000). Five-factor personality questionnaire. Kurgan: Publishing house of the Kurgan state University.

Klimova, E.M., Kamyshanov, A.A., Poruchkina, S.M., Zhilyaev, A.A., Ionkin, V.B., Mikhaylovsky, M.N. \& Deberdeeva, N.A. (2018). Subjective factors of occupational mobility. Modern Journal of Language Teaching Methods, 8(12), 49-57.

Korzhova, E.Yu. (2002). Psychological knowledge of the fate of man. St.Petersburg: ed. Russian State Pedagogical University named after A.I. Herzen, ed. Soyuz.

Kuprene E.V. \& Laptev L.G. (2016). Professional coping resource staff as an object of psychological research. Human Capital, 10(94), 67-72.

Lazarus, R. (1970). Theory of stress and psychophysiological studies. Emotional stress: physiological and psychological reactions. L. Levy and V.N. Myasishchev (Eds.). Leningrad: Medicine.

Leontiev, A.N. (1975). Activity. Consciousness. Personality. Moscow: Politizdat.

Leontiev, D.A. (2003). Psychology of meaning: nature, structure and dynamics of semantic reality. Moscow: Sense.

Leontiev, D.A. \& Rasskazova, E.I. (2006). Test of viability. Moscow: Meaning.

Libina, A.V. (2008). Coping intellect: a person in a difficult life situation. Moscow: Eksmo.

Maddi, S., Khoshaba D., Persico M., Lu J., Harvey R. \& Bleecker F. (2002). The Personality Construct of Hardiness: Relationships with Comprehensive Tests of Personality and Psychopathology. Journal of Research in Personality, 36, 72-85.

Maddi, S. \& Khoshaba D.M. (1994). Hardiness and Mental Health. Journal of Personality Assessment, 63(2), $265-274$.

Maklakov, A.G. (2001). Personal adaptive potential, its mobilization and forecasting in extreme conditions. Psychological journal, 22(1), 16-24.

Miloradova, N.G. \& Ishkov, A.D. (2019a). Development of the technique of the

universal social-and-psychological competences formation. International Journal of Applied Exercise Physiology, 8(2), 994-1002.

Miloradova, N.G. \& Ishkov, A.D. (2019b). Training of the highly qualified 
personnel in the postgraduate study in Russia and Tajikistan: results of the sociological poll. International Journal of Applied Exercise Physiology, 8(3), 373-380.

Mitin S.N., Kidinov A.V., Fedotov S.N., Leontev M.G., Bolotova A.K. \& Kalinin I.V. (2018). Modern models of career readiness. Modern Journal of Language Teaching Methods, 8(3), 78-86.

Mitin, S.N., Shukshina, L.V., Bazhdanova, Yu.V., Koretskaya, I.A. \& Vasyakin, B.S. (2017). Value and meaning attitudes as a factor of forming tolerant ethnic consciousness in the multicultural milieu of a higher education institution. Eurasian Journal of Analytical Chemistry, 12(7b), 1193-1200.

Mitina, I.D., Vasyakin B.S., Pozharskaya, E.L., Berezhnaja, M.S., Khudyakova, T.L. \& Kovaleva, N.B. (2017). The development of psychological and pedagogical support for the students' social and professional self-determination system. Modern Journal of Language Teaching Methods, 7(12), 275-285.

Nartova-Bochaver, S.K. (1997). "Coping Behavior" in the system of concepts of personality psychology. Psychological Journal, 18(5), 20-30.

Safronova, O.M. (2019). Features of perception of the life way of modern youngs and girls. Simbirsk Scientific Journal Vestnik, 4(38), 81-84.

Salakhova, V.B., Sidyacheva, N.V., Zotova, L.E., Klepach, Y.V., Rusyaeva, T.A., Belova, T.A. \& Buevich, S.Y. (2018a). Specific Features of Normative Ideals and Individual Priorities of the Deviant Personality. Modern Journal of Language Teaching Methods, 8(5), 232242.

Salakhova, V.B., Sokolovskaya, I.E., Ulyanova, I.V., Karina, O.V. \& Terekhova, A.I. (2019). Deviant behavior formation factors among students: aggressive behavior and internet risks. Práxis Educacional, 15(34), 683-694.

Salakhova, V.B., Zaretskiy, V.V., Kalinina, N.V., Artamonova, E.G., Efimova, O.I. \& Lekareva, E.E. (2018b). Existential psycho-correction of the value-meaning sphere of the personality of adolescents with deviant behavior. Modern Journal of Language Teaching Methods, 8(6), 294-302.

Shakurov, R.Kh. (2003). Psychology of meanings: theory of overcoming. Questions of Psychology, 5. URL: http://www.voppsy.ru/issues/2003/035/035018.htm

Solovieva, S.I. (2016). Bases of psychotherapy for "practically healthy". Medical Psychology in Russia, 3(38) URL: http://medpsy.ru/mprj/archiv_global/2016_3_38/nomer06.php

Vasilyuk, F.E. (1984). Psychology of experience. Moscow: Publishing House of Moscow University. 